\title{
THE USE OF SYÄME AS A PHONOLOGICAL MARKER IN SYRIAC
}

\author{
AARON MichaEL ButTS \\ THE CATHOLIC UNIVERSITY OF AMERICA
}

For J. F. 'Chip' Coakley

on his retirement

\begin{abstract}
It is well established that the primary use of syāmē in Syriac is to mark the morphological category of plurality. This study explores a secondary use of syāmē as a phonological marker for a final mid front vowel in Syriac. This occurs most frequently with Greek words in Syriac that ended in - $\eta$, or more rarely $-\varepsilon$ or $-a$, in the Greek source. It is proposed that the phonological use of syāmē can also explain the regularity and consistency with which syāmē occur with the feminine forms of the teen cardinal numbers.
\end{abstract}

It is well established that the primary use of syame '(lit.) placings' in Syriac is to mark the morphological category of plurality. ${ }^{1}$ The

* I would like to thank George A. Kiraz (Beth Mardutho: Syriac Institute) for discussing this paper with me as well as for adding several examples to those cited here. I would also like to thank the anonymous reviewer(s) at Hugoye who provided useful feedback. Finally, I am especially grateful to Lucas Van Rompay (Duke University) for his helpful comments. Note the following abbreviation: $\mathrm{CAD}=$ The Assyrian Dictionary of the Oriental Institute of the University of Chicago (Chicago, 1956-). 
singular noun sلحم /malkā/ 'king', for instance, is distinguished from the plural noun تلحسم/malkē/ 'kings' in the consonantal script of Syriac by the syame on the latter. ${ }^{2}$ This use of syame is attested already in the earliest Syriac manuscripts, such as London, Brit. Libr. Add. 12,150, which is dated to 411 CE. ${ }^{3}$ It should be noted that syame are not found in the Old Syriac inscriptions, e.g., حـ /bnay/ 'my children' (As16 [201/2 CE]; ed. Drijvers and Healey 1999: 73-74), or in the Old Syriac documents, e.g., احس '73/zabnin/ 'times' (P1.7 [243 CE]; ed. Drijvers and Healey 1999: 7374). ${ }^{4}$ While syame mark the morphological category of plurality in the vast majority of cases, this is not their only use in Syriac. Occasionally, syamè function as a phonological marker for a final mid front vowel in Syriac.

The occasional use of syamè as a phonological marker for a final mid front vowel is most common with Greek loanwords in Syriac that ended in $-\eta$ in the Greek source, as in the following examples: ${ }^{5}$

1 Brockelmann 1981: \$11; Duval 1881: §66; Kiraz 2012: \$225-234; Nöldeke 1904: \$16; Segal 1953: 5. For the history of the term syame along with alternative designations, such as näqzay saggiyanutāa 'points of plurality', see Kiraz 2012: §225.

2 As an aside, it should be pointed out that the $k$ in Syriac /malkēe/ 'kings' is not fricativized in contrast to earlier forms of Aramaic where it is, as is reflected in Biblical Aramaic malkin 'kings' (Ezra 4:20) < *malakin (see Rosenthal 1995: §51). This is due to an analogical development in Syriac whereby the plural base * malak- was replaced by the singular base * malk-

${ }^{3}$ A color image of this manuscript is available in Brock, Butts, Kiraz, and Van Rompay 2011: 457, where one can see several examples of syame marking plurality, e.g., గ م- o /saggi'è/ 'much' (col. 3, ln. 1). Jones (1998) has argued that many of the diacritical points after f. 40v of ms. Brit. Libr. Add. 12,150 were added secondarily; this does not, however, include syame, the use of which belongs to the original scribe (see at p. 439).

${ }^{4}$ Jones 1998: 435; Kiraz 2012: \$225.

${ }^{5}$ In each of these examples, the singular is assured by the context - or, it is at the very least highly likely. It is tempting to add to this list $\tau$ น (Liddell and Scott 1996: 1793-1794) > rseb 'price' (Sokoloff 2009: 527), which is often written $r$ with syamè. When written with syamè, however, this word always seems to take plural agreement. Thus, r $r$ is better analyzed as plurale tantum, probably on analogy to the semantically similar ris: 'price' (Sokoloff 2009: 309), which is also plurale tantum. It should be 


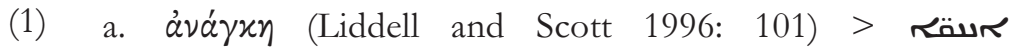

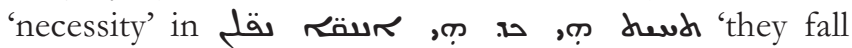
under the same necessity' (Qiyore of Edessa, Cause of the Liturgical Feasts, 103.20; ed. Macomber 1974).

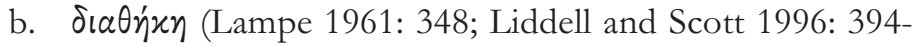

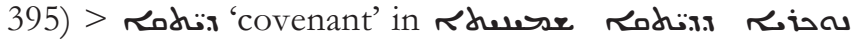
'stranger to the heavenly covenant' (History of St. Cyriacus and his Mother Julitta according to the Syriac ms. at the Library of the Royal Asiatic Society, f. 182r, ln. 10 [1569

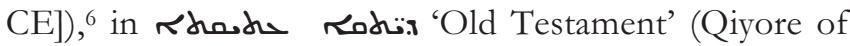
Edessa, Cause of the Liturgical Feasts, 20.26-21.1, 73.17, 92.17, 109.23, 171.6, 172.17-18; ed. Macomber 1974); ${ }^{7}$

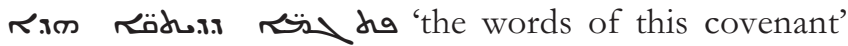
(Jer. 11:6; Mosul edition).

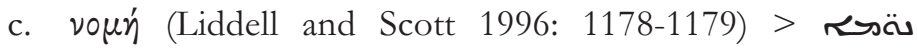

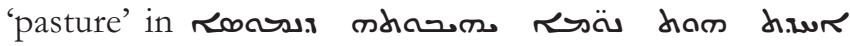
'the giving of the law had spread out' (Qiyore of Edessa, Cause of the Liturgical Feasts, 171.12-13; ed. Macomber 1974). 8

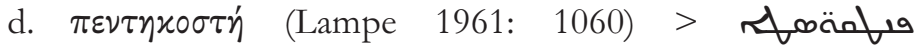

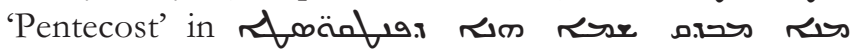

noted that the latter may well be a loanword from Akkadian dame 'blood money' (CAD D 79, sub 2b), even though it is not included in Kaufman 1974, especially since the Akkadian form is also plural. For the association between 422.

${ }^{6}$ The singular is assured by the following adjective that does not have syame as well as by the witnesses of other manuscripts that have roł. without syämè, such as ms. Sachau 222 (1881 CE; ed. Bedjan 1890-1897: 3.272.21).

${ }^{7}$ See also 94.14, 20; 146.20; 147.30; 162.21; 172.4 .

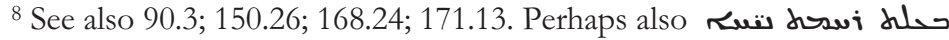

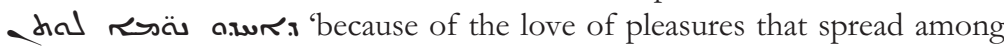
us' (Ishaq of Nineveh, Part 3, 104.16; ed. Chialà 2011). The form rä may be singular in this case, since $\sqrt{ }$ ' $h d$ 'to take' plus rso 'pasture' forms a common idiom 'to spread' (Sokoloff 2009: 900). It is, however, possible that rä is plural in this example due to attraction to the plural verb. Regardless, the editor's emendation (Chialà 2011: 104 n. 38) to sas without syämè should be rejected. 
'what does this word "Pentecost" signify' (Qiyore of Edessa, Six Explanations of the Liturgical Feasts, 160.4; 161.13; 162.4-5; ed. Macomber 1974). ${ }^{9}$

e. $\sigma \chi 0 \lambda \eta \dot{~(L i d d e l l ~ a n d ~ S c o t t ~ 1996: ~ 1747-1748) ~>~}$

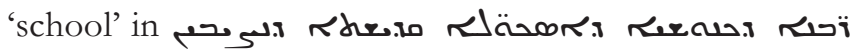
'the teachers of the community of the holy School of Nisibis' (Qiyore of Edessa, Six Explanations of the Liturgical Feasts, 45.24; ed. Macomber 1974). ${ }^{10}$

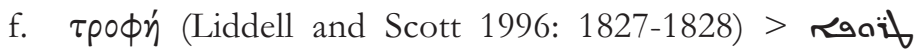

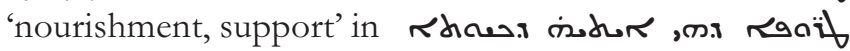
ris Rinun 'nourishment, which is purity and freedom from suffering' (Babai the Great, Commentary on the 'Gnostic Chapters' by Evagrius of Pontus, 468.14-15; ed. Frankenberg 1912).

g. Ű $\lambda \eta$ (Liddell and Scott 1996: 1847-1848) > همه 'matter' in مhostr rhana 'they introduce matter to the divine creation' (Qiyore of Edessa, Six Explanations of the Liturgical Feasts, 20.18-19; ed. Macomber 1974). ${ }^{11}$

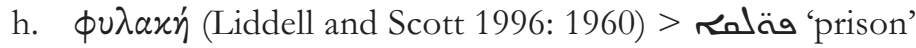

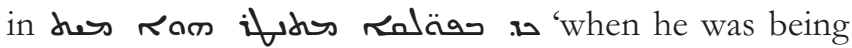
guarded in the prison, he died' (Yuhanon of Ephesus, Ecclesiastical History, Part 3, 158.22; ed. Brooks 1935). ${ }^{12}$

It should be noted that forms without syamè are much more common for all of these words. Regardless, in each of the cases in (1), the syamè serve as a phonological marker for a final mid front

${ }^{9}$ See also $160.1 ; 162.7 ; 164.1 ; 165.8,18 ; 187.20$.

10 Becker (2006: 104-105 with n. 79 [on p. 243]; see also 2010: 93 n. 10) suggests that the phonological use of syame occurs in the title of the Cause of the Foundation of the Schools: حلrod. Scher 1907: 13), which he would render The Cause of the Establishment of the Session of the School. It should be noted that one manuscript reads $\nabla$ Vم instead of

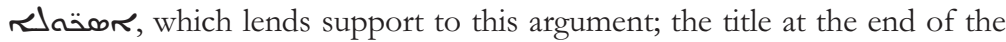
text, however, has the plural obsor (Scher 1907: 83.4; note, however, the lack of syamè), which weakens the argument.

11 The plural of this loanword only seems to be attested as $\ddot{\emptyset} \mathrm{am}$ (Sokoloff 2009: 335, 341).

12 The plural cannot be absolutely ruled out in the context, even if the singular seems much more likely. 
vowel. The writing of syame, thus, disambiguates the consonantal script of these Greek loanwords, which could be read with either final $-\bar{a}$ or final $-\bar{e}$, in the same way as it disambiguates the consonantal script of many masculine nouns, e.g., singular sلحم /malkā/ 'king' vs. plural تحلحم /malkēe/ 'kings'. The list in (1) is not exhaustive, but it would seem to provide enough evidence to establish that syame occasionally occur as a phonological marker for a final mid front vowel in Syriac reflecting $-\eta$ in the Greek source. ${ }^{13}$

Syriac syame also serve as a phonological marker for a final mid front vowel with several Greek proper nouns that ended in $-\eta$, as in the following examples: ${ }^{14}$

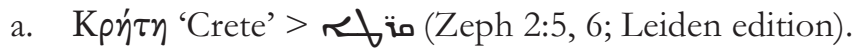

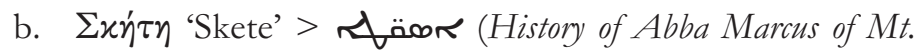
Tharmaka, according to ms. Yale Syriac 5, p. 36; ed. Look 1929: 1).

These cases are comparable to those cited in (1) in which syame disambiguate the consonantal script, which could be read with either final $-\bar{a}$ or final $-\bar{e}$.

The use of syamè as a phonological marker for final Greek $\eta$ has implications for the pronunciation of $\eta$ in the Koine Greek of Syria and Mesopotamia. In Attic Greek, $\eta$ was a long open-mid front $/ \varepsilon: / .{ }^{15}$ Some Koinē dialects preserved $\eta$ as an open-mid front $/ \varepsilon /$ into the Roman period, whereas others attest a merger of $\eta$ with the high front /i/, which could be written either เ or $\varepsilon ı .{ }^{16} \mathrm{~A}$ few spellings in the Greek documents from Syria and Mesopotamia suggest that Greek $\eta$ was at least beginning to merge to /i/ in this region by the Roman period. ${ }^{17}$ The use of syame as a phonological

13 Though many of these examples occur in Qiyore of Edessa's Six Explanations of the Liturgical Feasts, the phenomenon is certainly not limited to this text.

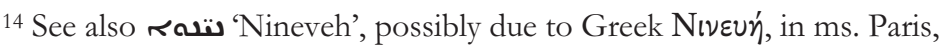
Bibl. Nat. 56, f. 191v (ed. Van Rompay 2015).

15 Allen 1987: 69-75; Woodard 2004: 617.

16 Allen 1987: 74-75; Gignac 1976-: 1.235-242; Mayser 1970: 46-54; Palmer 1934: 170; 1945: 1.

17 See Welles, Fink, and Gilliam 1959: 47 as well as the following spellings from the P.Euph. documents: $\dot{\eta}$ for $\varepsilon \dot{\imath}$ (P. Euph. 11.24 [232]); 
marker for final Greek $\eta$, however, suggests that some Syriac writers and/or scribes preserved a pronunciation of $\eta$ as a mid front vowel well into the Roman period, since the Syriac masculine plural status emphaticus ending was never realized as a high front vowel but always as mid front. The preservation of a mid front pronunciation of Greek $\eta$ in this area at this time can be corroborated by the representation of final Greek $-\eta$ by the voiceless glottal stop' in Syriac, which would have represented a final mid front vowel, in contrast to spellings with a final palatal glide $y$, which would have represented a final high front vowel, e.g.,

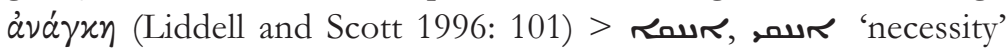
(Sokoloff 2009: 63). Thus, Syriac evidence suggests that Greek $\eta$ was beginning to merge to /i/ in this region by the Roman period (representations of final $-\eta$ with Syriac $y$ ), though at least some Syriac writers and/or scribes preserved its mid front realization well into the Roman Period (representations of final $-\eta$ with Syriac ' and the occasional use of syamé as a phonological marker). ${ }^{18}$

In addition to final Greek $-\eta$, syame more rarely serve as a phonological marker for final Greek $-\varepsilon$. This is, for instance, the case with the writing of the personal name 'Qiyore' in the Six Explanations of the Liturgical Feasts by Qiyore of Edessa (1.1; ed. Macomber 1974). This Syriac name derives from Greek Kũpe, a frozen vocative of Kũpos 'Cyrus'. Thus, in this case, the syamè in

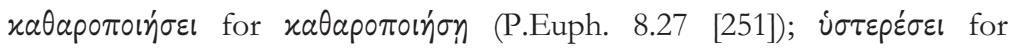

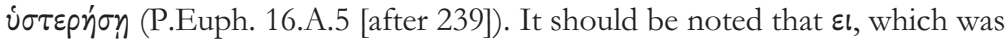
a long close-mid front /e:/ in Attic Greek, had merged with I as a high unrounded short /i/ by the Koinē Greek of the Roman and Byzantine periods (Allen 1987: 70; Gignac 1976-: 1.189-191, 235-262; Mayser 1970: 54-65; Palmer 1934: 170; 1945: 1). For this merger in the Greek of Syria and Mesopotamia, see Welles, Fink, and Gilliam 1959: 47; many additional spellings attesting this merger will also be found in the P.Euph. documents. The Greek P.Euph. documents are edited in Feissel and Gascou 1989; 1995; 2000; Feissel, Gascou, and Teixidor 1997. Images of these texts are available online at <http://www.papyrologie.paris-sorbonne.fr/menu1/ collections/pgrec/peuphrate.htm>.

18 The present author is currently completing a study that uses Greek loanwords in Syriac as a witness to the Greek of Late Antique Syria and Mesopotamia (as so-called Nebenüberlieferungen). 


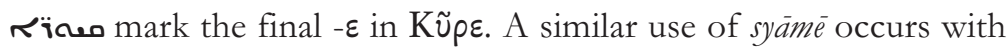
the writing of the Greek aorist passive infinitive $\sigma \phi u p ı \sigma \theta \tilde{\eta} v a l$ 'to be struck with hammers, beat' as ruhö̈aor with syamé in Part 3 of the Ecclesiastical History by Yuhanon of Ephesus (15.28; ed. Brooks 1935). In the editio princeps, Brooks proposed to emend this word by removing syämê. This emendation is, however, unnecessary, since the syame here are a phonological marker for final Greek - $\alpha$ l, which had merged with Greek $\varepsilon$ as a mid-front short /e/ by the Koinē Greek of the Roman and Byzantine periods. ${ }^{19}$

An interesting case of the use of syame for Greek $-\varepsilon$ is found in the following passage from the anonymous tract on accents in Brit. Libr. Add. 12,138 (899 CE), which is the only surviving manuscript of the East-Syriac 'Masora':20

Anonymous tract in East-Syriac 'Masora' (Brit. Libr. Add. 12,138 [899 CE])

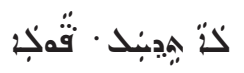

'Do not be afraid, Paul' (f. 306v, ln. $17=$ Acts 27:24)21

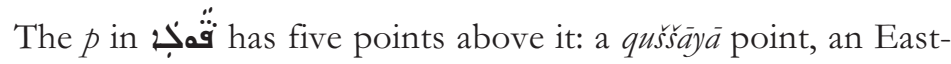
Syriac zqāpa with two points, as well as two additional points. ${ }^{22}$

19 Allen 1987: 79; Gignac 1976-: 1.191-193; Mayser 1970: 83-87. For this merger in the Greek of Syria and Mesopotamia, see Welles, Fink, and Gilliam 1959: 47 as well as the following selected spellings from the P.Euph.

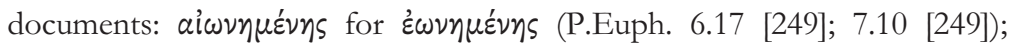

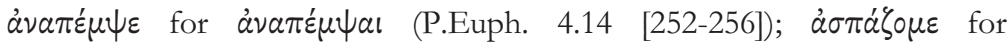

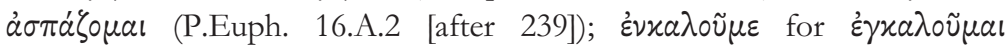

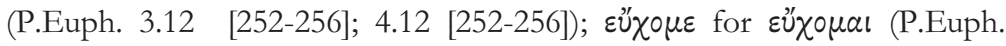

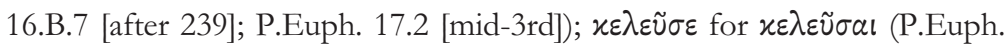

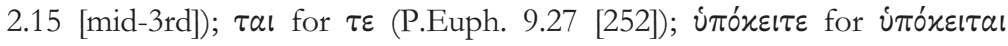

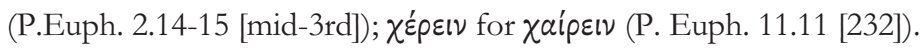

${ }^{20}$ For this anonymous tract, see Segal 1953: 79. For a facsimile edition of the entire manuscript, see Loopstra Forthcoming. I would like to thank Jonathan Loopstra (Capital University) for sharing his work with me prior to its publication.

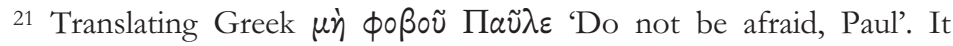
should be noted that both Segal (1953: 99 n. 1) and Kiraz (2012: §303) cite the folio as $303 \mathrm{v}$. 
Segal follows the author of the anonymous tract in interpreting these two additional points as a rähța accent, which 'joins two words closely together in a context to which a rising tone is suitable' (1953: 98-99). A similar interpretation is found in Kiraz's recent volume on Syriac orthography, where it is added that the two points are 'not to be confused' with syamè (2012: \$139). This analysis is, however, not without problems. The use of räbtă at the end of a word is found in a fair number of reliable examples. ${ }^{23} \mathrm{In}$ contrast, the use of räbta a at the beginning of a word is not so reliably attested. Following the anonymous tract on accents in Brit. Libr. Add. 12,138, Segal (1953: 99) provides three total examples, but comments that in all these examples one of the two points may not be part of råb̆å but a diacritical point' (n. 7). Given the uncertainty over the use of räbta $\bar{a}$ at the beginning of a word, an alternative analysis of the two additional points in قa in (3) is in order. These two points could represent syame being used as a phonological marker. In this case, the syame would represent the final $-\varepsilon$ in the Greek vọcative $\Pi \alpha \tilde{\lambda} \lambda \varepsilon$.

If the syamé in قُّبَ in (3) are analyzed as a phonological marker for final $-\varepsilon$, the Syriac vocalization with final $p t a \bar{h} h \bar{a}$ would then be a secondary development. In his Book of Splendors, Bar 'Ebroyo (d. 1286) explains that Greek personal names in Syriac that end in -os

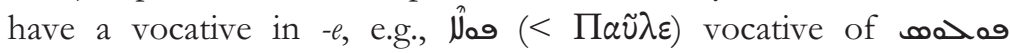

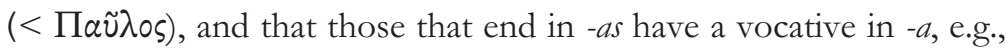

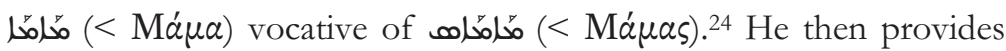
the following comment about the derivation of such words in East Syriac:

22 The same five points appear with this letter in the version of this verse found on f. $275 \mathrm{v}, \ln .1$ of Brit. Libr. Add. 12,138, which is not from the anonymous tract $(303 \mathrm{v}-308 \mathrm{v})$ but from the actual biblical samples.

${ }^{23}$ Segal (1953: 98-99), for instance, cites half a dozen.

24 The Syriac is edited in Moberg 1922: 166.16-22, and a German translation is available in Moberg 1907-1913: 1.145. It should be noted that Bar 'Ebroyo does not call these vocatives but diminutives (zu' "ärâ). 
Book of Splendors by Bar 'Ebroyo (ed. Moberg 1922)

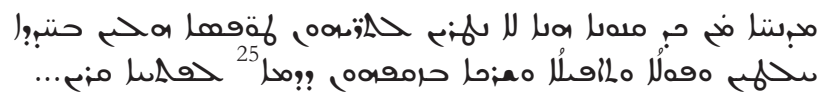

'The East Syrians, not keeping this rule, mix these two types with one another and read pwlā, $t^{\prime}$ pylä, etc., with their

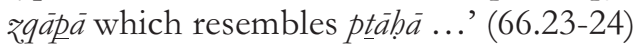

Thus, Bar 'Ebroyo states that the two Greek types -os and -as had been leveled to a single vocative in $-\bar{a}$ in East Syriac by his time (the thirteenth century). The form قَّمَ in in the East-Syriac 'Masora' establishes that this leveling had occurred already by 899 , several centuries prior to Bar 'Ebroyo. ${ }^{26}$ It is difficult to explain the discrepancy between the final $2 q a \bar{a} p \bar{a}$ given by Bar 'Ebroyo in his description of East Syriac and the final ptähä found in Brit. Libr. Add. 12,138. ${ }^{27}$ It should, however, be noted that both final ₹qapapa and $p$ tâha a are found for these forms in the later East-Syriac tradition; the

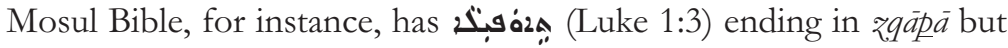
(Acts 27:24) ending in ptâăāa

Thus, it is proposed that the two additional points in قُّج that is, those points that are neither the qušsay $\bar{a}$ marker nor the East-Syriac zqäpā - are best analyzed as syamè. This syamè would have functioned as a phonological marker for final $-\varepsilon$ before East Syriac leveled the two types of vocatives of Greek personal names $(-e$ and $-a)$ to a single type in $-a / \bar{a}$. After the leveling, the syame would not have been analyzable, since the final vowel was no longer mid front. This would have made it possible for syame in this case to be reinterpreted as a räbtă accent, as they have been in the East-Syriac 'Masora' (Brit. Libr. Add. 12,138, f. 306v, ln. 17). ${ }^{28}$

25 The edition has though it is preferable to emend as above.

26 If the anonymous tract on accents $(303 \mathrm{v}-308 \mathrm{v})$ is older than the biblical samples in Brit. Libr. Add. 12,138, as Segal (1953: 7) supposes, then this date can be pushed even earlier.

27 Perhaps, the forms ending in ptāhāa are the result of West-Syriac influence, where the vocative of Greek personal names in -as ends in ptähă

${ }^{28} \mathrm{It}$ is from here, of course, that this analysis made its way into Segal 1953: 99 and more recently Kiraz 2012: \$303. 
Up to this point, all of the examples of syame functioning as a phonological marker for a final mid front vowel involve Greek words in Syriac. There is, however, a set of native Syriac words where syamé also function as a phonological marker (or at least did originally): the feminine forms of the teen cardinal numbers (11-19). The most commonly attested forms of the teen cardinal numbers are given in the chart in (5).

\begin{tabular}{|c|c|c|}
\hline & with masculine nouns & with feminine nouns \\
\hline 1 & بِّحِحْْ: & 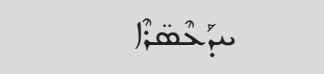 \\
\hline 2 & L & 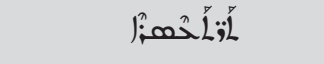 \\
\hline 3 & Lاحُحُحمَّ: & Lاحُدْحُفْ:ْ \\
\hline 4 & 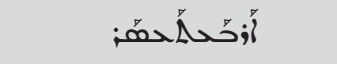 & | \\
\hline 5 & 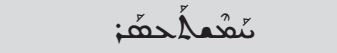 & 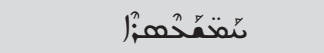 \\
\hline 6 & عهأَحمَّ: & 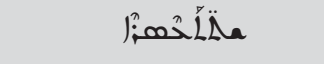 \\
\hline 7 & 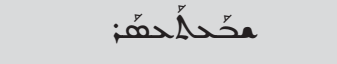 & مصحَخِّه:ُْ \\
\hline 8 & 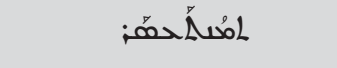 & 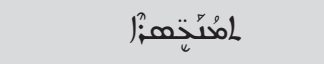 \\
\hline 9 & 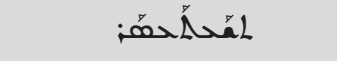 & 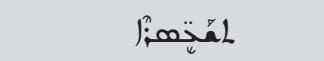 \\
\hline
\end{tabular}

In the manuscripts, there is a great deal of variation in the forms themselves as well as in which forms are written with syame. ${ }^{29}$ Notwithstanding this, however, syäme are most commonly found with the feminine forms of the teen cardinal numbers. This is due to the fact that it is the feminine forms of the teen cardinal numbers that end in $-\bar{e} .30$ This final $-\bar{e}$ is not etymologically related

29 Brockelmann 1981: §157; Coakley 2002: 134; Muraoka 2005: \44; Nöldeke 1904: \$148.

${ }^{30}$ So already Nöldeke 1904: $\$ 16$ and Hetzron 1977: 186 n. 1. 
to the Syriac masculine plural status emphaticus ending $-e^{-31}$ Thus, the feminine forms of the teen cardinal numbers represent another

31 This is certain since the same ending is found with these forms in Biblical Hebrew, which does not of course have the Aramaic masculine plural status emphaticus ending -è, e.g., šöss 'ésre 'thirteen (FEM)', which is written in the consonantal script as $s / s=s ' s h$. The etymology of the $-\bar{e}$ that occurs in the word for ten in feminine forms of the teen cardinal numbers in Hebrew and Syriac continues to defy explanation. Traditionally, it was connected with the feminine ending *-ay (see, e.g., Brockelmann 1908: \225Bd $\beta \alpha \alpha$ [p. 412]; 249c $\beta$ [p. 489]; 1981: \$106; Cowley 1910: \$80L; Joüon and Muraoka 2005: \$891, 100e; Moscati et al. 1964: \$12.33 [tentatively]; Wright 1890: 138; for the wider Semitic context of the feminine ending $*$-ay, see the bibliography and discussion in Layton 1990: 241-249). One would, however, expect the feminine ending $*$-ay to be realized as -ay in both Syriac and Hebrew, based on Syriac salway 'quail' (Sokoloff 2009: 1012; for additional examples, see Nöldeke 1904: \$83) and on Hebrew śáray (Gen. 11:30), the earlier name of Sarah. Ugaritic evidence adds further difficulties to the traditional etymology that relates the $-\bar{e}$ in the word for ten in feminine forms of the teen cardinal numbers in Hebrew and Syriac to the feminine ending $*_{-a y}$. In Ugaritic, the word for ten in teen cardinal numbers

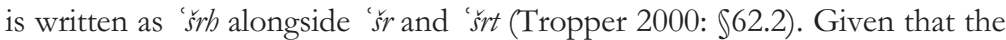
word for ten is also written with final $-b$ in the feminine of these forms in Hebrew, it is likely that Ugaritic 'šrh is cognate to the Hebrew forms as well as to the Syriac forms, where the mater lectionis will have been changed from $b$ to ' (for this change in Syriac, compare the orthography of the feminine singular status absolutus ending, which is consistently - ' in Syriac but was - $b$ in Old Aramaic [Degen 1969: \$34] with Biblical Aramaic attesting both forms [Rosenthal 1995: \$42]). The $-b$ in Ugaritic 's $s h b$ cannot be a reflex of the feminine ending $*_{-a y}$ because: 1 . the feminine ending $*_{-a y}$ is probably realized as $-y$ in Ugaritic (Tropper 2000: \$52.4 with the comments in Pardee 2003/2004: 176-177); 2. Ugaritic $b$ never functions as a mater lectionis and is always consonantal in Ugaritic (Tropper 2000: \$21.342.2; Huehnergard 2012: 21). Thus, while the analysis of the final $-b$ in Ugaritic 's s rh remains uncertain (Bordreuil and Pardee 2009: 36; Huehnergard 2012: 49; see the discussion in Tropper 2000: \$62.201), the Ugaritic evidence casts further doubt on analyzing the ending $-\bar{e}$ on the word for ten in feminine forms of the teen cardinal numbers in Biblical Hebrew and Syriac as the feminine ending *-ay (contra Joüon and Muraoka 2005: \$100e, who doubt whether the Ugaritic evidence can be used to show that $b$ in Hebrew 'śrb was originally consonantal). It should be noted here in passing that Hetzron (1977) has proposed that the final $-\bar{e}$ in these Hebrew and Syriac forms is - at least partially - the result of language contact with Akkadian. This is, however, 
case in which syäme (at least originally) serve as a phonological marker for a final mid front vowel in Syriac - this time with native Syriac words. The fact that syame are occasionally found with the masculine forms of the teen cardinal numbers, which do not end in $-\bar{e}$, as well as with other numbers, which also do not end in $-\bar{e}$, suggests that the phonological use of syame was secondarily reinterpreted as a morphological marker of plurality by at least some writers and/or scribes. This, however, represents a secondary development. The regularity and consistency with which syame occur with the feminine forms of the teen cardinal numbers suggest that the origin of their use with numbers is to be found there, where they functioned originally as a phonological marker, and it is from there that they spread to other numbers. ${ }^{32}$

The connection between syame and the end of a word is interestingly enough reflected in the orthography of the Syriac incantation bowls. ${ }^{33}$ In contrast to the situation in Classical Syriac, syame often occur on the final 'alap in the Syriac incantation bowls,

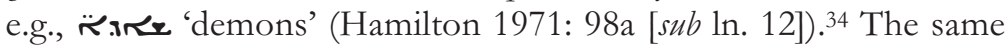

unlikely given what is known about the contact between these languages as well as about contact-induced change more broadly.

32 The result of such an extension can be illustrated by Christian Palestinian Aramaic, where syamè are used with masculine and feminine forms of the teen cardinal numbers as well as with many other forms of the numbers (for the forms, see Müller-Kessler 1991: \$4.3.1).

${ }^{33}$ Syriac incantation bowls, also called 'magic bowls', are earthenware bowls that are inscribed with incantations in ink. The bowls are typically thought to stem from the late Sasanian period (sixth to seventh century), though both earlier and later dates have been suggested. Two scripts are attested in the Syriac bowls: Estrangela and a related script that is often termed Proto-Manichaean'. The language of the Syriac bowls differs in a number of ways from Classical Syriac (Van Rompay 1990). Collections of Syriac incantation bowls are available in Hamilton 1971: 98-164 as well as more recently Moriggi 2004: 235-294 (for the history of publication of Syriac bowls, see Moriggi 2004: 1-6, 47-48 with further references). The Syriac incantation bowls have parallels in Mandaic and Jewish Babylonian Aramaic.

34 This feature is not mentioned in Hamilton 1971: $48-49$ or Moriggi 2004. In addition, syame are unfortunately not marked in the texts in the appendix of Moriggi 2004, leaving this interesting difference between Classical Syriac and the language of the Syriac incantation bowls 
orthography is found in the Syriac leather amulets edited by Ph. Gignoux (1987),35 e.g., ״̈ 'demons' (Amulet 1, ln. 16). This orthography of writing syame on the last letter of the word indicates the close connection between syame and the phonology of the last syllable.

This study has aimed to shed light on a minor, but interesting orthographic feature of Syriac that is not recorded in the standard grammars, such as those of Duval (1881) and Nöldeke (1904): the occasional use of syamè as a phonological marker for a final mid front vowel in Syriac. ${ }^{36}$ This use of syame is due to a reanalysis of the relationship between syame and the ending $-\bar{e}$ of masculine plural status emphaticus nouns, such as jتح /malkē/ 'kings'. Some writers and/or scribes re-analyzed what was originally a morphological marker of plurality in nouns such as تخلحم /malkē/ 'kings' as a phonological marker for a final mid front vowel. This reanalysis enabled syame to be extended to non-plural words that ended in a mid front vowel, such as Greek words in Syriac that ended in $-\eta$, or more rarely $-\varepsilon$ or $-\alpha l$, in the Greek source as well as to the feminine forms of the teen cardinal numbers. ${ }^{37}$

\section{BIBLIOGRAPHY}

Allen, W. S. 1987. Vox Graeca: A Guide to the Pronunciation of Classical Greek (3rd ed.). Cambridge.

Becker, A. H. 2006. Fear of God and the Beginning of Wisdom. The School of Nisibis and Christian Scholastic Culture in Late Antique Mesopotamia. Philadelphia.

indiscernible to the reader (syame are marked in Hamilton's texts, even though they are written in square script).

${ }^{35}$ For this edition, see the review article in Wesselius 1991.

36 This use was, however, noted by Van Rompay (apud Salvesen 1997: 245 n. 66), Becker (2010: 93 n. 10), and Kiraz (2012: \$158).

37 Following a similar development, syàmé occasionally function as a phonological marker for a final mid front vowel in Christian Sogdian texts (Sims-Williams, apud Kiraz 2012: §621). 
"The Comparative Study of 'Scholasticism' in Late Antique Mesopotamia: Rabbis and East Syrians," AJS Review 34: 91-113.

Bedjan, P. 1890-1897. Acta Martyrum et Sanctorum (7 vols.). Paris Leipzig.

Bordreuil, P. and D. Pardee. 2009. A Manual of Ugaritic (LAWS 3). Winona Lake.

Brock, S. P. 1967. "Greek Words in the Syriac Gospels (vet and pe)," Le Muséon 80 (1967): 389-426.

Brock, S. P., A. M. Butts, G. A. Kiraz, and L. Van Rompay. 2011. Gorgias Encyclopedic Dictionary of the Syriac Heritage. Piscataway.

Brockelmann, C. 1908. Grundriß der vergleichenden Grammatik der semitischen Sprachen, Vol. I. Laut- und Formenlebre. Berlin. 1981. Syrische Grammatik (13th ed.). Leipzig.

Brooks, E. W. 1935. Iohannis Ephesini. Historiae Ecclesiasticae. Pars Tertia (CSCO 105). Louvain.

Chialà, S. 2011. Isacco di Ninive. Terza collezione (CSCO 637-638). Louvain.

Coakley, J. F. 2002. Robinson's Paradigms and Exercises in Syriac Grammar (5th ed.). Oxford.

Cowley, A. E. 1910. Gesenius' Hebrew Grammar (2nd ed.). Oxford.

Degen, R. 1969. Altaramäische Grammatik. Wiesbaden.

Drijvers, H. J. W. and J. F. Healey. 1999. The Old Syriac Inscriptions of Edessa and Osrboene. Leiden.

Duval, R. 1881. Traité de grammaire syriaque. Paris.

Feissel, D. and J. Gascou. 1989. "Documents d'archives romains inédits du Moyen-Euphrate (IIIe siècle après J.-C.)," CRAI 1989: 535-561.

. 1995. "Documents d'archives romains inédits du moyen Euphrate (III" s. après J.-C.). I. Les pétitions (P. Euphr. 1 à 5)," Journal des Savants: 65-119. 
. 2000. "Documents d'archives romains inédits du moyen Euphrate (III s. après J.-C.). III. Actes diverses et lettres (P. Euphr. 11 à 17)," Journal des Savants: 157-208.

Feissel, D., J. Gascou, and J. Teixidor. 1997. "Documents d'archives romains inédits du moyen Euphrate (III ${ }^{e}$ s. après J.-C.). II. Les actes de vente-achat (P. Euphr. 6 à 10)," Journal des Savants: 3-57.

Frankenberg, W. 1912. Evagrius Ponticus. Berlin.

Gignac, F. T. 1976-. A Grammar of the Greek papyri of the Roman and Byzantine Periods. Milan.

Gignoux, P. 1987. Incantations magiques syriaques. Louvain.

Hamilton, V. P. 1971. Syriac incantation bowls. Ph.D. Diss., Brandeis University.

Hetzron, R. 1977. "Innovations in the Semitic Numeral System," JSS 22: 167-201.

Huehnergard, J. 2012. An Introduction to Ugaritic. Peabody, MA.

Jones, F. S. 1998. "Early Syriac Pointing in and behind British Museum Additional Manuscript 12,150," in R. Lavenant, S.J. (ed.), Symposium Syriacum VII (Orientalia Christiana Analecta 256). Rome. 429-444.

Joüon, P. and T. Muraoka. 1991. A Grammar of Biblical Hebrew. Rome.

Kaufman, S. A. 1974. Akkadian Influences on Aramaic. Chicago.

Kiraz, G. A. 2012. Türrạs Mamllā. A Grammar of the Syriac Language. Piscataway.

Layton, S. C. 1990. Archaic Features of Canaanite Personal Names in the Hebrew Bible. Atlanta.

Liddell, H. and R. Scott (revised by H. Stuart Jones and R. McKenzie). 1996. A Greek-English Lexicon. Oxford.

Look, A. E. 1929. The History of Abba Marcus of Mount Tharmaka. Oxford.

Loopstra, J. Forthcoming. An East Syrian Manuscript of the Syriac 'Masora' to 899 CE. Piscataway. 
Macomber, W. F. 1974. Six Explanations of the Liturgical Feasts by Cyrus of Edessa (CSCO 355-336). Louvain.

Mayser, M. 1970. Grammatik der griechischen Papyri aus der Ptolemäerzeit, Vol. 1. Laut- und Wortlehre, Part 1. Einleitung und Lautlehre (2nd ed.). Berlin.

Moberg, A. 1907-1913. Buch der Strablen. Die grössere Grammatik des Barbebräus. Leipzig. . 1922. Le Livre des splendeurs. La grande grammaire de Grégoire Barbebraeus. Lund.

Moriggi, M. 2004. La lingua delle coppe magiche siriache (Quaderni di Semitistica 21). Firenze.

Moscati, S. et al. 1964. An Introduction to the Comparative Grammar of the Semitic Languages. Wiesbaden.

Müller-Kessler, Ch. 1991. Grammatik des Christlich-PalästinischAramäischen, Part 1. Schriftlebre, Lautlehre, Formenlebre (Texte und Studien zur Orientalistik 6). Hildesheim.

Muraoka, T. 2005. Classical Syriac. A Basic Grammar with a Chrestomathy (2nd ed.; PLO ns 19). Wiesbaden.

Nöldeke, Th. 1904. Compendious Syriac Grammar. Translated from the second and improved German edition by James A. Crichton. Leipzig.

Palmer, L. R. 1934. "Prolegomena to a Grammar of the PostPtolemaic Papyri," JTS 35: 170-175. . 1945. A Grammar of the Post-Ptolemaic Papyri. London.

Pardee, D. 2003/2004. Review of Tropper 2000 (online version). AfO 50.

Rosenthal, F. 1995. A Grammar of Biblical Aramaic (PLO ns 5). Wiesbaden.

Salvesen, A. 1997. "Hexaplaric Readings in Išo dad of Merv's Commentary on Genesis," in J. Frishman and L. Van Rompay (eds.), The Book of Genesis in Jewish and Oriental Christian Interpretation (Traditio Exegetica Graeca 5). Louvain. 229-252.

Scher, A. 1907. Mar Barhadbšabba 'Arbaya. Évêque de Halwan (VTe siècle). Cause de la fondation des écoles (PO 4.4). Paris. 
Segal, J. B. 1953. The Diacritical Point and the Accents in Syriac (London Oriental Series 2). London.

Sokoloff, M. 2009. A Syriac Lexicon. A Translation from the Latin, Correction, Expansion, and Update of C. Brockelmann's Lexicon Syriacum. Winona Lake - Piscataway.

Tropper, J. 2000. Ugaritische Grammatik. Münster.

Van Rompay, L. 1990. "Some Remarks on the Language of Syriac Incantation Texts," in R. Lavenant, S.J. (ed.), V Symposium Syriacum 1988 (Orientalia Christiania Analecta 236). Rome. 269281.

2015. "L'histoire du Couvent des Syriens (Wadi al-Natrun, Égypte), à la lumière des colophons de la Bibliothèque nationale de France," in F. Briquel Chatonnet and M. Debié (eds.), Manuscripta Syriaca. Des sources de première main (Cahiers d'études syriaques). Paris.

Welles, C. B., R. O. Fink, and J. F. Gilliam. 1959. The Excavations at Dura-Europus. Final Report V, Part 1. The Parchments and Papyri. New Haven.

Wesselius, J. W. 1991. "New Syriac magical texts," BiOr 48: 70516.

Woodard, R. D. 2004. "Attic Greek," in R. D. Woodard (ed.), The Cambridge Encyclopedia of the World's Ancient Languages. Cambridge. 614-649.

Wright, W. 1890. Lectures on the Comparative Grammar of the Semitic Languages. Cambridge. 
